\title{
AC 2008-1285: PERFORMANCE ASSESSMENT FOR CIVIL ENGINEERING CURRICULUM
}

\section{Jean-Pierre Bardet, University of Southern California}

Jean-Pierre Bardet is Professor of Civil and Environmental Engineering and Chair of the Sonny Astani Department of Civil and Environmental Engineering. He received his Ph.D. from the California Institute of Technology.

\section{Gisele Ragusa, University of Southern California}

Gisele Ragusa is Associate Professor of Clinical Education, and Director of Undergraduate and Teacher Education Programs at the Rossier School of Education of the University of Southern California. She received a Ph.D. from the University of Southern California. Her research interests and areas of expertise include: teacher education and retention, literacy education, teacher education supervision, multimedia literacy, early childhood special education, deaf education, as well as bilingual elementary teacher education.

\section{Fred Meyer, United States Military Academy}

Colonel Karl F. (Fred) Meyer is an Associate Professor and Civil Engineering Program Director in the Department of Civil and Mechanical Engineering at the United States Military Academy (USMA) at West Point, NY. He is a registered Professional Engineer in Virginia. COL Meyer received a B.S. degree from USMA in 1984, and M.S. and Ph.D. degrees in Civil Engineering from the Georgia Institute of Technology in 1993 and 2002. 


\title{
Performance Assessment for Civil Engineering Curriculum
}

\begin{abstract}
The accreditation of engineering education programs by the Accreditation Board for Engineering and Technology (ABET) requires the direct assessment of student's learning to ensure they meet the requirements of particular program outcomes. Past attempts of measuring student's learning in Civil Engineering have largely relied on a few isolated data points and unreliable satisfaction surveys. Hereafter the authors propose a systematic approach for directly assessing the student performance across an entire program which includes the current ABET requirement as well as the Body of Knowledge (BOK) of the American Society of Civil Engineering (ASCE). The approach is based on embedded signature assessments and concept inventories, which originate from the field of educational psychology. These direct assessment methods lead to quantitative assessments of student performance without dramatically increasing faculty work load and generating tedious data collection; they enhance what is typically accomplished in the evaluation and grading of student work. The greatest benefit of using embedded signatures and concept inventories is to provide a rapid, multi-factored, quantitative assessment, and to provide instructors and administrators with the immediate, comprehensive feedback they need to promptly address student needs. This relatively simple yet thorough assessment process enables administrators to devote time to curriculum improvements instead of collecting and compiling assessment data with limited application focus. The performance methodology, although tested in this particular case with Civil Engineering, is applicable to other fields of Engineering.
\end{abstract}

\section{Introduction}

In response to the requirements of the Accreditation Board for Engineering and Technology (ABET) for assessing the performance of students in Civil Engineering in relation to particular program outcomes, many educational institutions have developed assessment methods based on satisfaction surveys, senior-level capstone design courses, and Engineer-in-Training examinations. In the past, assessors have struggled to find realistic and acceptable ways to assess student achievements across entire programs so that they meet ABET requirements as well as other professional recommendations, e.g., the Body of Knowledge ${ }^{3}$ (BOK) of the American Society of Civil Engineering (ASCE). Many institutions have painfully realized that the assessments of student learning performance can result in dramatically increasing faculty work load and generating timeconsuming data collection with uncertain results.

Inspired by past work on student's assessment ${ }^{7}$, the objective of the paper is to explore the application of concepts originating from the field of educational psychology to engineering education, and to propose efficient and effective ways to assess student learning performance. 
Following the introduction, the first section of the paper reviews the background for assessing student's learning, especially the reasons why higher education had to become more accountable in delivering relevant engineering education; the second section reviews basic concepts in educational psychology relevant to performance assessment; and the last section summarizes some preliminary results on how to measure student's learning and achievements in relation to particular program objectives.

\section{Background}

The National Academy of Engineering (NAE) has alerted the Nation that engineering education must adapt to world changes in technology and society for the US to strengthen its workforce and face the challenges of globalization ${ }^{12,13}$. NAE $^{13}$ quotes the National Science Board "The organizational structures for educating, maintaining skills, and employing science and engineering talent in the workforce are diverse and their interrelationships complex and dynamic. As a result, production and employment of scientists and engineers are not well understood as a system ${ }^{14}$." NAE states that "although progress is being made in engineering education, much remains to be done in developing research base underlying best practices in engineering education ${ }^{18}$ and faculty practice generally ${ }^{2} . "$ NAE presents a suite of recommendations summarized in Table 1.

Table 1. Excerpts from NAE Recommendations ${ }^{13}$.

- The B.S. degree should be considered as a pre-engineering or "engineer in training" degree.

- Engineering programs should be accredited at both the B.S. and M.S. levels so that the M.S. degree can be recognized as the engineering "professional" degree.

- Institutions should take advantage of the flexibility inherent in the EC2000 accreditation criteria of ABET, Incorporated in developing curricula, and students should be introduced to the "essence" of engineering early in their undergraduate careers.

- Engineering educators should introduce interdisciplinary learning in the undergraduate curriculum and explore the use of case studies of engineering successes and failures as a learning tool.

- The engineering education establishment should participate in efforts to public understanding of engineering and the technology literacy of the public and efforts to improve math, science, and engineering education at the K-12 level.

ABET, the primary accrediting body for engineering undergraduate programs, has for goal of ensuring the quality of undergraduate engineering science and technology programs through rigorous review and monitoring. As listed in Table 2, ABET approved a set of hard and professional skills that graduates must possess ${ }^{16}$. These skills extend beyond the minimalist standard of engineering practice to include professional standards that are of high quality, multidisciplinary, global and with collaborative focus.

The American Society of Civil Engineering (ASCE) is actively engaged in articulating an inspirational global vision for the future of civil engineering ${ }^{4}$. ASCE attempts to align stronger academic experience with anticipated future application-based workplace requirements. $\mathrm{ASCE}^{3}$ supports the attainment of a "Body of Knowledge" for entry into the practice of civil engineering at the professional level. This would be accomplished through the adoption of appropriate engineering education and experience requirements as a prerequisite for licensure. Fulfillment of this Body of Knowledge will combine a 
baccalaureate degree; a master's degree, or approximately 30 coordinated graduate or upper level undergraduate credits or the equivalent agency/organization/professional society courses providing equal quality and rigor; and appropriate experience based upon broad technical and professional practice guidelines which provide sufficient flexibility for a wide range of roles in engineering practice.

Table 2. ABET outcome criteria for engineering baccalaureate graduates.

\begin{tabular}{|c|c|}
\hline \multirow{5}{*}{ Hard skills } & 3a: An ability to apply knowledge of mathematics, science, and engineering \\
\hline & 3b: An ability to design and conduct experiments as well as to analyze and interpret data \\
\hline & $\begin{array}{l}\text { 3c: An ability to design a system, component, or process to meet desired needs within } \\
\text { realistic constraints such as economic, environmental, social, political, ethical, heath and } \\
\text { safety, manufacturability, and sustainability. }\end{array}$ \\
\hline & 3e: An ability to identify, formulate, and solve engineering problems. \\
\hline & $\begin{array}{l}\text { 3k: An ability to use the techniques, skills, and modern engineering tools necessary for } \\
\text { engineering practice }\end{array}$ \\
\hline \multirow{5}{*}{$\begin{array}{l}\text { Professional } \\
\text { Skills }\end{array}$} & 3d: An ability to function on multi-disciplinary teams \\
\hline & 3f: An understanding of professional and ethical responsibility \\
\hline & 3g: An ability to communicate effectively \\
\hline & $\begin{array}{l}\text { 3h: The broad education necessary to understand the impact of engineering solutions in a } \\
\text { global, economic, environmental and societal context. }\end{array}$ \\
\hline & 3j: A knowledge of contemporary issues. \\
\hline
\end{tabular}

\section{Review of education improvements in Civil Engineering}

Civil engineering is a broad field of engineering dealing with the planning, design, construction, maintenance and management of physical infrastructure networks, e.g., power plants, bridges, roads, railways, structures, water supply, irrigation, the natural environment, sewer, flood control, transportation and traffic ${ }^{19}$. Educational programs and practices in civil engineering have been incrementally revised and adapted over the years. Typically a BS program in civil engineering is comprised of a sequence of courses in Mathematics, Physics, Chemistry, Biology, Humanities, Business, and a few other fields of Engineering. Table 3 shows an example of curriculum in civil engineering at the University of Southern California (USC), which is accredited by ABET. This program is representative of many other curricula in universities and colleges throughout the United States. The program consists of a series of 40 courses, which can be regrouped in 9 main subject categories. Students take all their mathematics, physics and chemistry courses as freshman and sophomore, become gradually exposed to civil engineering over four years, and specialize in civil engineering as junior and senior.

So far most educational institutions have responded to the challenging tasks of reforming engineering education with traditional approaches, which unfortunately have produced incremental and slow improvements. Reformers face often tremendous difficulties and even resistance in their attempts of modifying curricula that have been gradually perfected through years of incremental revisions. Many educational institutions are attempting to reform engineering education based on their own experiences in engineering. However they struggle with incremental and introverted changes because they do not use expertise beyond engineering, such as educational psychology. 
Table 3. Example of ABET-accredited BS program in Civil Engineering.

\begin{tabular}{|c|c|c|c|c|}
\hline & Course & Description & Prerequisites & Co-requisites \\
\hline & Math 108 or Math Placem & & & \\
\hline & CHEM 050/Chemistry Pla & Basic requirement for taking courses in chemistry & & \\
\hline & Junior or Senior Standing & Prerequisite for some courses & & \\
\hline & CE 106 & Design and Planning of Civil Engineering Systems & & \\
\hline & ENGR 102 & Engineering Freshman Academy & & \\
\hline & Math 125 & Calculus I & Math 108 or Math Placement Exam & \\
\hline & Writ 140 & Writing and Critical Reasoning & & \\
\hline & Category 6: Social Issues & & & \\
\hline & CE 107 & Introduction to Civil Engineering Graphics & & \\
\hline 5 & CE 108 & Introduction to Computer Methods in Civil Engineering & & \\
\hline$\stackrel{2}{c}$ & Math 126 & Calculus II & Math 125 & \\
\hline & Phys 151L & Fundamentals of Physics I: Mechanics and Thermodynamic & Math 125 or Math 126 or Math 226 & \\
\hline & Select One CHEM Course & & & \\
\hline & CE 205 & Statics & Phys 151L & \\
\hline N & Math 226 & Calculus III & Math 126 & \\
\hline$\overline{\bar{\tau}}$ & Phys 152L & Fundamentals of Physics II: Electricity and Magnetism & Phys 151L, Math 126 & Math 226 \\
\hline & Select One GE Course & & & \\
\hline & Select One GE Course & & & \\
\hline 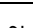 & CE 225 & Mechanics of Deformable Bodies & CE 205 & \\
\hline 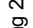 & CE 207L & Introduction to Design of Structural Systems & CE 107, CE 205 & CE 225 \\
\hline$\stackrel{2}{c}$ & Math 245 & Mathematics of Physics and Engineering I & Math 226 & \\
\hline के & CE 325 & Dynamics & CE 205 & \\
\hline & Select One Course & & & \\
\hline & CE 309 & Fluid Mechanics & Math 226 & CE 325 \\
\hline$m$ & CE 358 & Theory of Structures I & CE 225 & \\
\hline & CE 456 & Design of Steel Structures & CE 207L, CE 225 & CE 358 \\
\hline & CE 334L & Mechanical Behavior of Materials & CE 225 or AME 204 & \\
\hline & Select One GE Course & & & \\
\hline & CE 473 & Engineering Law, Finance and Ethics & & \\
\hline 0 & CE 451 & Water Resources Engineering & CE 309 or ENE 410 & \\
\hline 气 & CE 467L & Geotechnical Engineering & CE 225 & \\
\hline के & Select One EE Course & & & \\
\hline & Select One Kernel & & & \\
\hline & CE 408 & Risk Analysis in Civil Engineering & CE 225, Math 226 & \\
\hline$\theta$ & CE 453 & Water Quality Control & CHEM 105aL or CHEM 115aL & CE 408 or CHE 405 , CE 309 or ENE $41 \mathrm{C}$ \\
\hline & CE 471 & Principles of Transportation Engineering & & \\
\hline ப̈ & Select One Kernel & & & \\
\hline 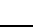 & Select One CE Elective & & & \\
\hline & Select One Capstone & & & \\
\hline $\begin{array}{l}\Delta \\
0\end{array}$ & CE 402 & Computer Methods in Engineering & CE 108, Math 245 & \\
\hline 气 & Writ 340 & Advanced Writing & Writ 140 & \\
\hline के & Select One CE Elective & & & \\
\hline & Select One GE Course & & & \\
\hline
\end{tabular}

There is an urgent need for devising learning assessment tools that yield useful information for educators to improve effectively curriculum and course delivery mechanisms. As added benefits, these tools may assist educators and administrators in convincing external reviewers, e.g. ABET reviewers, that their particular programs meet specific outcomes and ABET requirements.

\section{Educational Psychology as a Means of Transforming Engineering Curriculum}

To accomplish this global vision of linking course work to field-based applications, the authors posit to apply widely researched educational psychology principles and practices to the engineering curriculum. These practices include:

- vignette-based instruction,

- embedded signature assignments,

- rubric judged laboratory experiences,

- value judged internships, and

- concept inventory assessments in all courses in the courses.

All five of these teaching practices combine assessment to instruction and are linked to student performance. Vignette-based instruction is described as a provision of instruction where students are provided with real world vignettes or workplace problems and must solve these vignette based issues or problems using principles perspectives and practices that they have learned in courses ${ }^{1}$. These are often group experiences and the resulting solutions are judged using carefully crafted numeric rubrics. Embedded signature 
assignments are critical assignments that are linked to accreditation standards and are summative measures of course content. They range from a criterion referenced examination to group or solo project. The assignments offer proof of within course learning ${ }^{15}$. Rubric judged laboratory experiences have most often been applied to K-12 sciences coursework however they are beginning to be applied to university course-based lab experiences. Rubrics for the laboratories are aligned to content standards (in the case of the proposal, to ABET standards and the ASCE Body of Knowledge). Numeric scores are assigned to the rubrics allowing the course instructors to quantify human behavior for statistical analyses and comparison across groups ${ }^{6}$. Value judged internships are often used in education, social work or other human services professions where internships are required as a precursor to graduation. The employer and the university intern supervisor use numeric measures to judge the performance of the intern. These measures link the course content to the interns' field practice. Concept inventories have been used in education for decades. These inventories are force choice surveys in which misnomers related to content are contrasted with concept truisms in an attempt to statistically judge increases in concept knowledge over time or as a pre and post test measure. These formative and summative assessment-based experiences have been tested in K-12 and human services higher education programs but are not widely used in engineering programs. The authors goal is to use these instructional practices and associate assessment in the undergraduate civil engineering coursework with an ultimate goal of scaling up these practices school-wide in the Viterbi School of Engineering and eventually in other science based curriculum at USC.

\section{Preliminary research results}

The long-term objective of this research is to reform engineering education by applying well established techniques in educational psychology to engineering and other scientific curricula. These techniques have been developed and tested in education settings predominantly in K-12 schools, but have not received significant attention in university settings to measure student learning and education program performance particularly in engineering and other science oriented schools and academic departments.

Examples of civil engineering curriculum can be analyzed using both educational psychology and ASCE and ABET professional requirements. The educational psychology analysis invokes techniques such as concept inventory and vignette-based instruction. The analysis also accounts for best practices and professional requirements defined in the Body Of Knowledge (BOK) of ASCE, and the ABET accreditation requirements.

One of the key elements of this research consists of designing and implementing a performance system that monitors the progress and success of curriculum changes. The performance assessment is constructed using embedded signatures. Figure 1 illustrates how to embed signatures and relate course grades, graduation, and performance assessments. As shown in Fig. 1, the vertical axis represents a progression toward graduation, whereas the inclined axis represents a progression toward other goals set by different requirements, e.g., ABET accreditation and graduation based on minimum grade 
point average. This representation implies that not all students may satisfy both graduation and ABET requirements. Course grades, which are relevant for graduation, may not be sufficient for other requirements. Past attempts of measuring the ABET performance of Civil Engineering students have relied on a single senior-level capstone design course and end-of-course surveys. The authors propose a more direct and systematic assessment of student performance across an entire program which accounts for BOK and ABET requirements. This assessment, which measures quantitative performance, does not increase faculty workload and data collection; it builds upon the current practices of evaluating and grading students through the USC Blackboard system. The embedded signatures are defined by instructors and link desired program outcomes and course tests, e.g., projects, quizzes and exams. This monitoring system is anticipated to become accepted by instructors because it produces immediate quantitative feedback for promptly addressing course and program weaknesses.

The performance monitoring system is anticipated to yield a large volume of almost realtime information. This rapid feedback system departs from the time-consuming corrective processes which are occasionally in place through educational systems. It is emphasized that the proposed approach relies on quantitative performance measurements, instead of subjective interpretations such as student satisfaction surveys.

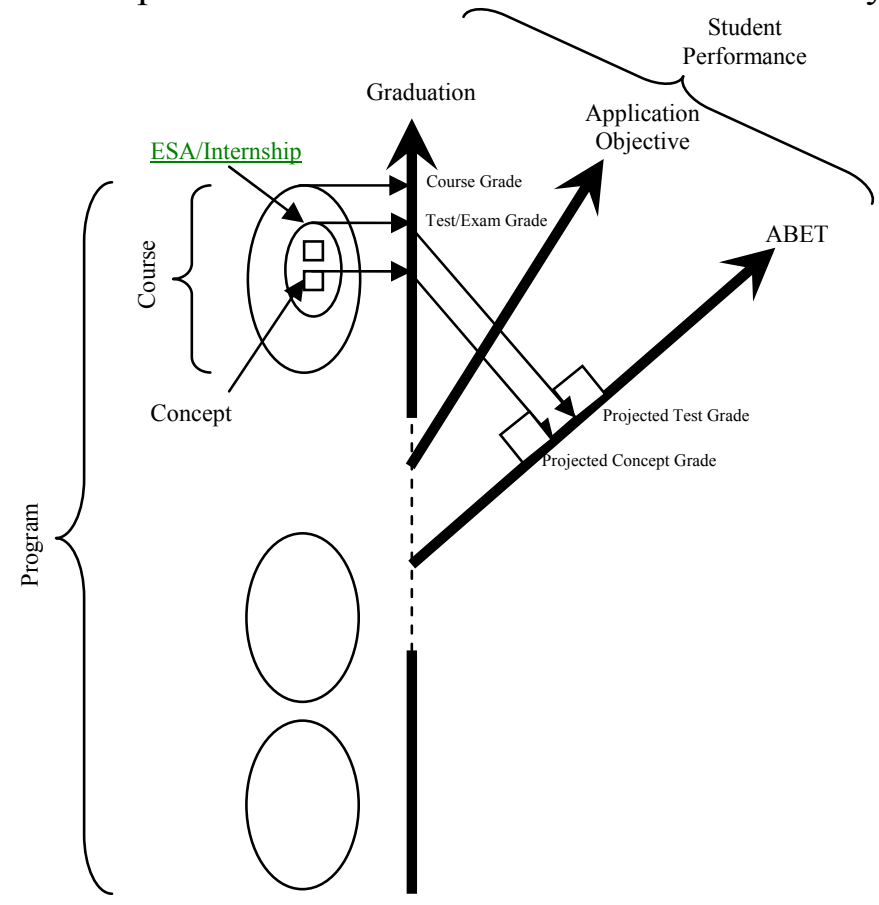

Figure 1. Integrated performance assessments for graduation and other requirements.

\section{Conclusion}

The accreditation of engineering education programs by ABET requires the direct assessment of student performance to ensure they meet the requirements of particular program outcomes. Past attempts of measuring student performances in Civil Engineering have largely relied on sparse and unreliable data collection. Hereafter the 
authors have proposed a systematic approach for directly assessing the student performance across an entire program which includes the current ABET requirement as well as the Body of Knowledge (BOK) of the American Society of Civil Engineering (ASCE). The approach is based on embedded signature assessments and concept inventories, which originate from the field of educational psychology. These direct assessment methods lead to quantitative assessments of student performance without dramatically increasing faculty work load and generating tedious data collection; they enhance what is typically accomplished in the evaluation and grading of student work. The performance methodology, although tested with Civil Engineering, is applicable to other fields of Engineering.

\section{References}

1. Anderson, L., and Krathwohl, D. Eds. 2000, “A taxonomy for learning, teaching, and assessing: A revision of Bloom's taxonomy of educational objectives." Boston, MA: Longman.

2. Arreola, R., M. Theall, and L. Aleamoni, 2003, "Beyond Scholarship: Recognizing the Multiple Roles of the Professoriate," Presented at the 2003 American Educational Research Association convention. Available on line at http://www.cedanet.com/meta/Beynd\%20Scholarship.pdf, Accessed April 19, 2005.

3. ASCE (American Society of Civil Engineers), 2004, "Civil Engineering Body of Knowledge for the 21rst Century," Reston, Va. Available on line at http://www.asce.org/professional/educ/bodyofknowledge.cfm, Accessed April 3, 2005.

4. ASCE (American Society of Civil Engineers), 2007, "The Vision for Civil Engineering in 2025," Report of the summit on the future of Civil Engineering, ASCE, p. 96.

5. Bloom, B. S. 1984. Taxonomy of educational objectives. Boston, MA: Allyn and Bacon, Pearson Education.

6. Champion, R. 2002 Taking Measure: Choose the right data for the job. Journal of Staff Development, 23(3).

7. Heron, J., 2000, "Co-operative inquiry: research with rather than on people," in P. Reason and H. Bradbury (eds.), Handbook of Action Research, London: Sage.

8. Honey, P., Mumford, A., 1982, "Manual of Learning Styles," London: P. Honey.

9. Jensen, E., 2000, Brain-Based Learning. San Diego: Brain Store Incorporated.

10. Laurillard, D., 2001, "Rethinking University Teaching," 2nd ed., London: Taylor \& Francis.

11. Meyers, K., S. Bert, 2007, "A Technique for Program-Wide Direct Assessment of Student Performance," Proceedings of ASEE Conference, Honolulu, Hawaii.

12. NAE, 2004, "The Engineer of 2020," National Academy of Engineering, The National Academy Press, Washington DC.

13. NAE, 2005, "Educating the Engineer of 2020," National Academy of Engineering, The National Academy Press, Washington DC.

14. NSB (National Science Board), 2003, "The Science and Engineering Workforce: Realizing America's Potentials," Report 03-69, Arlington, VA, National Science Foundation, Available online at http://www.nsf.gov/nsb/documents/2003/nsb0369/nsb0369.pdf, Accessed July 8, 2005.

15. Pecheone, Raymond L., Chung, and Ruth R. 2006. "Evidence in Teacher Education: The Performance Assessment for California Teachers (PACT)," Journal of Teacher Education. 57: 22-36.

16. Shuman, L. J., Besterfield-Sacre, M. and J. McGourty, 2005, "The ABET Professionals Skills Can they be taught? Can they be assessed?" Journal of Engineering Education, Vol. 94, No. 1, pp. 4156.

17. Tanner, K., Allen, D. 2004, "Approaches to Biology Teaching and Learning: Learning Styles and the Problem of Instructional Selection Engaging All Students in Science Courses." Cell Biol Educ 3:197201. 
18. Wankat, P. C., R. M. Felder, K. A. Smith and F. S. Oreowicz, 2002, "The Engineering Approach to the Scholarship of Teaching and Learning," pp. 217-237 in Disciplinary Styles in the Scholarship of Teaching and Learning: Exploring Common Ground, M. T. Huber and S. Morreales, eds., Washington, D.C., American Association for Higher Education, Available online at http://www.ncsu.edu/fielder $\sim$ public/papers/Scholarship chapter.pdf, Accessed July 8, 2005.

19. Wikipedia, 2007, "Civil Engineering," http://en.wikipedia.org/wiki/Civil_engineering, Accessed May 6, 2007.

20. Williams, R., 2003, "Education for the Profession Formerly Known as Engineering," The Chronicle of higher Education, Vol. 49, No. 20, p. B12. 